\title{
Effects of Crop Rotations and Tillage on Pratylenchus spp. in the Semiarid Pacific Northwest United States
}

Richard W. Smiley, Professor, Stephen Machado, Associate Professor, Jennifer A. Gourlie, Faculty Research Assistant, Larry C. Pritchett, Faculty Research Assistant, Guiping Yan, Research Associate, and Erling E. Jacobsen, Farm Manager, Oregon State University, Columbia Basin Agricultural Research Center, Pendleton 97801

\begin{abstract}
Smiley, R. W., Machado, S., Gourlie, J. A., Pritchett, L. C., Yan, G. P., and Jacobsen, E. E. 2013. Effects of crop rotations and tillage on Pratylenchus spp. in the semiarid Pacific Northwest United States. Plant Dis. 97:537-546.

There is interest in converting rainfed cropping systems in the Pacific Northwest from a 2-year rotation of winter wheat and cultivated fallow to direct-seed (no-till) systems that include chemical fallow, spring cereals, and food legume and brassica crops. Little information is available regarding effects of these changes on plant-parasitic nematodes. Eight cropping systems in a low-precipitation region $(<330 \mathrm{~mm})$ were compared over 9 years. Each phase of each rotation occurred each year. The density of Pratylenchus spp. was greater in cultivated than chemical fallow, became greater with increasing frequency of host crops, and was inversely associated with precipitation $\left(R^{2}=0.92, \alpha<\right.$

and winter pea were greater $(\alpha<0.01)$ than after harvesting spring barley or spring pea. Camelina also produced low densities. Winter wheat led to a greater density of Pratylenchus neglectus and spring wheat led to a greater density of $P$. thornei. Density of Pratylenchus spp. was correlated $\left(R^{2}=0.88, \alpha<0.01\right)$ but generally higher when detected by real-time polymerase chain reaction on DNA extracts from soil than when detected by a traditional method. Selection of different Pratylenchus spp. by different wheat cultivars or growth habit must be addressed to minimize the level of nematode risk to future plantings of intolerant crops.
\end{abstract} $0.01)$. Densities after harvesting mustard, spring wheat, winter wheat,
The root-lesion nematodes Pratylenchus neglectus (Rensch) Filipjev Schuurmanns \& Stekhoven and $P$. thornei Sher \& Allen suppress yields of rainfed cereals in temperate regions worldwide $(5,43)$. These species are present in $90 \%$ of fields in low-precipitation regions (150 to $300 \mathrm{~mm}$ ) of north-central Oregon and southcentral Washington, and the nematode density in soil is above a potentially damaging level in perhaps $60 \%$ of the fields (42). Rainfed wheat (Triticum aestivum L.) in the region is planted on 1.5 million ha annually. In all, $90 \%$ of the hectares in the $<330-\mathrm{mm}$ annual precipitation area are managed as a monoculture "rotation" of winter wheat (10 months) and summer fallow (14 months) because precipitation occurs mostly from late autumn (October) to early spring (April) and the amount is highly variable from year to year $(31,32)$. Winters are cold and intervals of frozen soil are common. Warm to hot days and cool nights prevail during the dry summer period when crops are maturing. Optimal grain yield for cereal crops is dependent upon healthy root systems capable of extracting water stored deeply in the soil profile. Most fallow is managed as a mechanically prepared "dust mulch".

Direct seeding into non-tilled chemical summer fallow is of strong interest but still lags behind mechanical cultivation in the low-precipitation region because direct-seed systems have historically been less profitable than mechanical fallow systems when fuel and fertilizer expenses were not excessive $(2,16,30,31)$. Threeyear rotations of winter wheat, a spring crop, and chemical summer fallow are also of interest but have not been widely adopted in lowprecipitation zones because they also have been less profitable and have had greater year-to-year economic risk compared with winter wheat-summer fallow rotations $(30,32)$. Although practiced on only a small percentage of hectares, most direct-seeded, annually planted fields in the low-precipitation region are planted repeatedly

Corresponding author: R. Smiley, E-mail: richard.smiley@ oregonstate.edu

Accepted for publication 12 November 2012.

http://dx.doi.org/10.1094/PDIS-08-12-0788-RE

(C) 2013 The American Phytopathological Society to spring wheat or spring barley (Hordeum vulgare L.) because these crops have been more profitable than rotation with crops such as yellow mustard (Sinapsis alba L.), canola (Brassica napus L.), or camelina (Camelina sativa (L.) Crantz), albeit less profitable than winter wheat rotated with fallow $(15,30)$. Winter field pea (Pisum sativum L. var. arvense (L.) Poir) is another crop of interest to growers in low-precipitation regions, and spring pea ( $P$. sativum L.) is commonly produced in regions where higher precipitation $(>450 \mathrm{~mm})$ is more favorable for annual cropping systems.

Densities of Pratylenchus spp. following fallow are generally lower than densities immediately following wheat $(19,21,42)$. Marley and Littler (17) associated reduced water-use efficiency in notill wheat, as compared with wheat planted into cultivated soil, to root injury caused by elevated densities of Pratylenchus thornei in the direct-seed system. Ornat et al. (22) reported that density of $P$. neglectus in the spring was reduced more by a combination of tillage and fallow than by fallow alone, and that the percentage of juveniles containing spores of parasitic Pasteuria spp. was greater in soil that had not been cultivated. However, Thompson (50) found more $P$. thornei in no-till than in cultivated fallow and Strausbaugh et al. (47) detected fewer Pratylenchus spp. in chemical than in cultivated fallow. In 2 of 5 years, Paulitz et al. (24) detected fewer $P$. neglectus in irrigated winter wheat that was planted without tillage than into cultivated soil, and no differences among tillage treatments occurred in other years. Brmež et al. (4), Smiley et al. (42), and Smiley and Machado (41) did not detect differences in Pratylenchus spp. density between chemical and cultivated fallows.

The density of Pratylenchus spp. is often correlated with the frequency of cereal crops $(9,29)$. Many wheat and winter pea cultivars appear to be particularly good hosts but barley is generally considered a poorer host than wheat $(13,41,42,50,55,57)$. In studies of multiple cultivars of many crop species, Hollaway et al. (13) and Taylor et al. (50) reported that field pea were resistant to both $P$. thornei and $P$. neglectus, that lentil (Lens culinaris Medik.) was resistant to $P$. thornei, that chickpea (Cicer arietinium L.) was susceptible to $P$. neglectus, and that canola (B. napus L.) was moderately resistant to $P$. thornei but susceptible to $P$. neglectus. Owen et al. (23) also reported that densities of $P$. thornei were greatly 
reduced following canola compared with wheat. Oilseed rape $(B$. napus L. subsp. oleifera (DC.) Metzg.) was also shown to be a good host of Pratylenchus spp. (1,58). Nevertheless, certain Brassica spp. can be used as biofumigant crops to reduce final nematode densities when the crop is macerated into soil as a green manure (25). Brassica spp. cultivars used as biofumigant crops contain elevated concentrations of certain glucosinolates which are not directly nematicidal (7) but release toxic isothiocyanate molecules following tissue damage, as when foliage is macerated and incorporated into soil. Potter et al. $(25,26)$ reported that roots of lines of B. napus L. (canola, or oilseed rape) and B. oxyrrhina (Coss.) Willk. (a wild species from Morocco) contained higher concentrations of 2-phenylethyl glucosinolate than lines of B. rapa L. (B. campestris L.; field mustard), B. nigra (L.) W. Koch (black mustard), and B. carinata A. Braun (Ethiopian mustard), and intermediate levels occurred in roots of B. juncea (L.) Czernj. \& Coss (brown mustard). Suppression of $P$. neglectus was negatively associated with root concentrations of 2-phenylethyl glucosinolate. In the semiarid regions of the Pacific Northwest, the brassica crops, mainly canola, mustard, and camelina, are grown as seed crops and are seldom, if ever, rototilled into soil as a biofumigant crop because all cropping systems must place highest consideration on availability of limited water resources. We are not aware of reports for effects of camelina on densities of Pratylenchus spp.

Both $P$. neglectus and $P$. thornei have reduced yields of annually cropped spring wheat by as much as $70 \%$ in Oregon $(45,46)$. It was also demonstrated in those studies that spring wheat with roots heavily infested by $P$. neglectus and $P$. thornei had canopy temperatures elevated as much as $4^{\circ} \mathrm{C}$ higher than in adjacent plots, where nematode populations were suppressed by applying a nematicide. Increased plant canopy temperature is directly correlated with water stress in wheat $(6,39)$. Root dysfunction caused by Pratylenchus spp. appeared to reduce the capacity of spring wheat to extract deeply stored water late in the growing season. Similarly, a greater tolerance of barley to $P$. thornei compared with wheat enabled barley to have greater efficiency in extracting and in being more responsive than wheat to stored soil moisture in a year with limited in-crop precipitation (53). Invasion of roots by Pratylenchus spp. also reduces the capacity of wheat to extract plant nutrients from soil (54).

A replicated multiyear experiment was established during 2003 to examine multidisciplinary aspects of eight representative cropping systems at a low-precipitation site infested with $P$. neglectus and $P$. thornei. Smiley and Machado (41) previously reported an inverse relationship between density of $P$. neglectus and yield of winter wheat during the first 5 years of this experiment, and that winter wheat treatments most affected by the nematode also extracted the least amount of water from the soil profile. This article reports associations between cropping systems and further evaluations of nematode densities over a 9-year period. During the last year of the experiment, inoculum densities for P. neglectus and P. thornei were compared using three methods, including real-time polymerase chain reaction (PCR) on DNA extracted from soil and two traditional extraction and morphological identification methods.

\section{Materials and Methods}

The experiment was performed at the Columbia Basin Agricultural Research Center, $1 \mathrm{~km}$ southeast of Moro, Sherman County, OR $\left(45^{\circ} 29.041^{\prime} \mathrm{N}\right.$ and $\left.120^{\circ} 43.127^{\prime} \mathrm{W}\right)$. The site is at $575 \mathrm{~m}$ of elevation and receives $282 \mathrm{~mm}$ of mean annual precipitation, nearly all of which occurs from late autumn (October) through spring (May). Mean daily air temperature is $-1^{\circ} \mathrm{C}$ during January and $19^{\circ} \mathrm{C}$ during July and August. Soil is a moderately deep (mostly $>120 \mathrm{~cm}$ ) Walla Walla silt loam; a coarse-silty, mixed, superactive, mesic Typic Haploxeroll. Daily precipitation was measured at an official U.S. National Weather Service recording site located $0.5 \mathrm{~km}$ from the experimental site.

Cropping systems. A uniform crop of spring wheat was planted over the intended experimental area during 2003. The experimental area was mapped into 42 plots of 15 by $105 \mathrm{~m}$ arranged as 14 treat- ments of eight crop rotations, randomized within each of three blocks. Each phase of each rotation was present each year to allow data for each treatment to be collected every year. Crops and cultivars or the type of fallow are shown in Table 1. Crops were harvested in late July or early August. A strip following the centerline of each 15-m wide plot was harvested using a commercial combine with a 5.5-m header, and grain yield was measured using a weigh wagon to determine yield per treatment.

Rotation 1. Two-year rotation of winter wheat and cultivated fallow. After harvest, the field was not cultivated until mid-April of the following (fallow) year. Glyphosate was applied as needed in the fall and spring. In April, primary tillage was conducted to a depth of $15 \mathrm{~cm}$ using a John Deere 1600 cultivator fitted with chisel plow turning points, followed by sweep cultivation to a depth of $13 \mathrm{~cm}$ using the same cultivator equipped with $30-\mathrm{cm}$ wide sweeps. Plots were rod-weeded at a depth of 8 to $10 \mathrm{~cm}$ whenever necessary to control weeds. Rod-weeding is the control of weeds by pulling a longitudinal square rod that is rotating backward below the soil surface. Plots were generally rod-weeded two or three times from May to August. In accordance with industry standards and based on soil sampling, anhydrous ammonia and gypsum were shank-applied into fallow during September to meet soil fertility requirements based upon target yields for the region. Soft-white winter wheat cultivars were planted into moist soil at 200 to 244 seeds $/ \mathrm{m}^{2}$ in mid-September using a John Deere 7616 $\mathrm{HZ}$ drill (Deere and Co.) with 40-cm row spacing. In-crop herbicides were applied as necessary.

Rotation 2. Two-year rotation of winter wheat and chemical fallow. Glyphosate was applied to control weeds three to four times during the chemical fallow phase. The fallowed plots were directseeded at a shallow depth and a rate of 244 seeds $/ \mathrm{m}^{2}$ using a Fabro Drill (Fabro Ltd.) during late September or early October. Seed was planted into moist or dry soil, depending upon weather conditions each year. Urea was banded $2.5 \mathrm{~cm}$ below the seed and ammonium sulfate was applied with the seed, each based upon industry standards and results of soil tests and target yields. In-crop herbicides were applied as necessary.

Rotation 3. Annual winter wheat. Plots were sprayed in late September or early October with glyphosate to control summer weeds. Plots were then direct-seeded during October or early November at a shallow depth and a rate of 220 to 240 seeds $/ \mathrm{m}^{2}$ using the Fabro disk-type drill with $30-\mathrm{cm}$ row spacing. A blend of urea and ammonium sulfate was banded $2.5 \mathrm{~cm}$ below the seed during planting, and herbicides were applied to the crop in accordance with industry standards.

Rotations 4 and 5. Annual spring wheat and spring barley. Plots were sprayed with glyphosate in late September or early October. In April, the annual spring wheat and spring barley plots were direct-seeded at rates within the range of 222 to 322 seeds $/ \mathrm{m}^{2}$, depending upon anticipated moisture available each year. The Fabro drill was used to plant soft-white spring wheat and two-rowed spring feed barley cultivars. Fertilizer and herbicide applications were as described for the annual winter wheat treatment.

Rotation 6. Three-year rotation of winter wheat, spring barley, and chemical fallow. Management practices for winter wheat following chemical fallow and the chemical fallow were the same as in the 2-year direct-seed rotation. Practices for spring barley following winter wheat were the same as for the annual spring barley treatment.

Rotation 7. Two-year rotation of winter wheat and winter pea. Following winter wheat harvest, plots were sprayed with glyphosate during late September to early October. Plots were then seeded with feed-type winter field pea cultivars at $78 \mathrm{seeds} / \mathrm{m}^{2}$ during October or early November using the Fabro drill. Granular inoculant was applied with the seed. Starter fertilizer ( $\mathrm{N}$ at $9 \mathrm{~kg} / \mathrm{ha}$ ) was banded below the seed, at a depth of $7.5 \mathrm{~cm}$. Herbicides were applied in accordance with standard practice. When winter pea plants succumbed to winterkill, the plots were replanted to spring field pea (Table 1). After the pea crop was harvested in late July or early August, glyphosate was applied to prepare plots for planting winter 
wheat. In October or early November, winter wheat was seeded at 244 seeds $/ \mathrm{m}^{2}$ using the Fabro drill. Urea was banded $2.5 \mathrm{~cm}$ below the seed during planting, and starter fertilizer (ammonium sulfate) was applied with the seed. In-crop herbicides were applied as necessary.

Rotation 8. Flexible cropping sequences (Flex crop). Two directseed flexible cropping treatments (rotations $8 \mathrm{~A}$ and $8 \mathrm{~B}$ ) were examined. Each treatment allowed independent and complete annual flexibility in selecting the crop species produced, with decisions based upon market prices, soil moisture available before planting, and occurrences of weeds and diseases. Cropping decisions were made by consensus of the project leader and the scientists and farmers who served on an advisory committee for this experiment. Crops grown in these rotations (Table 1) were winter wheat or spring-planted wheat, barley, yellow mustard, canola, or camelina. Management was as described for direct-seed annual crops.

Soil sampling and nematode extraction. Soil was collected each year to assess Pratylenchus spp. populations in individual treatments when soil was moist shortly before or after spring crops were planted, and at a time when fall-planted crops were still small following periods of frozen soil during the winter. In a similar environment, the density of $P$. neglectus during the spring was strongly correlated with the density measured in the autumn (8). Sampling dates were during late March or early April each year. Samples during 2004 to 2011 consisted of 20 cores $(2.5 \mathrm{~cm}$ in diameter by $30 \mathrm{~cm}$ deep) composited for each plot; 14 treatments $\times$ 3 replicates $=42$ samples. A larger volume of soil was collected during 2012 by doubling the sampling intensity. Samples were stored at field moisture level at $4^{\circ} \mathrm{C}$ for up to 7 days before being transported to a commercial nematode-testing laboratory for extraction and identification of genera present. Supplemental extractions and species identifications were performed in our laboratory.

Western Laboratories. Soil samples were sent annually to Western Laboratories (Parma, ID) for nematode extraction and identification using traditional methods. The lab typically moistens soils uniformly and incubates them at ambient temperature for up to 1 week to minimize differences in nematode extraction efficiency due to differences in soil moisture content. A modified elutriation method (14) was used to extract all soil-dwelling nematodes from 250 -g subsamples of soil plus root fragments (H. Kreeft, personal communication). Using an Oosterbrink elutriator, coarse material was collected on a $500-\mu \mathrm{m}$ sieve and nematodes on a stack of two $38-\mu \mathrm{m}$ and two 32- $\mu \mathrm{m}$ sieves. Nematodes were washed into 100$\mathrm{ml}$ cups, suspensions were stored overnight, and settled nematodes were transferred to 50-ml centrifuge tubes and concentrated by $3,200 \mathrm{rpm}$ for $5 \mathrm{~min}$. Water was discarded, replaced by magnesium sulfate solution at specific gravity 1.80 , mixed by spatula, and centrifuged again for $4 \mathrm{~min}$. The supernatant solution containing nematodes was passed over a $20-\mu \mathrm{m}$ sieve, transferred to another 50-ml tube, and allowed to settle for at least $2 \mathrm{~h}$ before counting.

Enumeration of nematodes was performed by reducing the volume of suspension in the 50 - $\mathrm{ml}$ tubes to $10 \mathrm{ml}$, mixing the remaining suspension in a mini-vortex mixer for $5 \mathrm{~s}$, removing $4 \mathrm{ml}$ of suspension, placing $1 \mathrm{ml}$ on a Peter's counting slide, counting and identifying all plant-parasitic nematode genera on the slide, and reporting nematodes per kilogram of oven-dry soil.

Root Disease Testing Service. During 2012, soil samples from the 42 plots were mixed thoroughly and a field-moist 500-g sub-

Table 1. Crop and management treatments over 9 years (2004 to 2012) in a long-term experiment at Moro, OR

\begin{tabular}{|c|c|c|c|c|c|c|c|c|c|c|c|}
\hline \multirow[b]{2}{*}{ Treatment $^{\mathrm{x}}$} & \multirow[b]{2}{*}{$\mathbf{R N}^{\mathbf{y}}$} & \multirow[b]{2}{*}{ Phase $^{\mathrm{z}}$} & \multicolumn{9}{|c|}{ Crop and cultivar or fallow type during each harvest yearw } \\
\hline & & & 2004 & 2005 & 2006 & 2007 & 2008 & 2009 & 2010 & 2011 & 2012 \\
\hline \multirow[t]{2}{*}{ WW/CvF } & 1 & $1 \mathrm{~A}$ & $\begin{array}{l}\text { WW } \\
\text { Tubbs }\end{array}$ & $\mathrm{CvF}$ & $\begin{array}{c}\text { WW } \\
\text { Stephens }\end{array}$ & $\mathrm{CvF}$ & $\begin{array}{c}\text { WW } \\
\text { ORCF101 }\end{array}$ & $\mathrm{CvF}$ & $\begin{array}{c}\text { WW } \\
\text { ORCF102 }\end{array}$ & $\mathrm{CvF}$ & $\begin{array}{c}\text { WW } \\
\text { ORCF101 }\end{array}$ \\
\hline & & $1 \mathrm{~B}$ & $\mathrm{CvF}$ & $\begin{array}{c}\text { WW } \\
\text { Tubbs }\end{array}$ & $\mathrm{CvF}$ & $\begin{array}{c}\text { WW } \\
\text { Stephens }\end{array}$ & $\mathrm{CvF}$ & $\begin{array}{c}\text { WW } \\
\text { Tubbs‘06 }\end{array}$ & $\mathrm{CvF}$ & $\begin{array}{c}\text { WW } \\
\text { ORCF101 }\end{array}$ & $\mathrm{CvF}$ \\
\hline \multirow[t]{2}{*}{$\mathrm{WW} / \mathrm{ChF}$} & 2 & $2 \mathrm{~A}$ & $\begin{array}{l}\text { WW } \\
\text { Tubbs }\end{array}$ & $\mathrm{ChF}$ & $\begin{array}{c}\text { WW } \\
\text { Stephens }\end{array}$ & $\mathrm{ChF}$ & $\begin{array}{c}\text { WW } \\
\text { ORCF101 }\end{array}$ & $\mathrm{ChF}$ & $\begin{array}{c}\text { WW } \\
\text { ORCF102 }\end{array}$ & $\mathrm{ChF}$ & $\begin{array}{c}\text { WW } \\
\text { ORCF101 }\end{array}$ \\
\hline & & 2B & $\mathrm{ChF}$ & $\begin{array}{l}\text { WW } \\
\text { Tubbs }\end{array}$ & $\mathrm{ChF}$ & $\begin{array}{c}\text { WW } \\
\text { Stephens }\end{array}$ & $\mathrm{ChF}$ & $\begin{array}{c}\text { WW } \\
\text { Tubbs‘06 }\end{array}$ & $\mathrm{ChF}$ & $\begin{array}{c}\text { WW } \\
\text { ORCF101 }\end{array}$ & $\mathrm{ChF}$ \\
\hline Annual WW & 3 & 3 & $\begin{array}{l}\text { WW } \\
\text { Tubbs }\end{array}$ & $\begin{array}{c}\text { WW } \\
\text { Tubbs }\end{array}$ & $\begin{array}{c}\text { WW } \\
\text { Stephens }\end{array}$ & $\begin{array}{c}\text { WW } \\
\text { ORCF101 }\end{array}$ & $\begin{array}{c}\text { WW } \\
\text { ORCF101 }\end{array}$ & $\begin{array}{c}\text { WW } \\
\text { Tubbs'06 }\end{array}$ & $\begin{array}{c}\text { WW } \\
\text { ORCF102 }\end{array}$ & $\begin{array}{c}\text { WW } \\
\text { ORCF101 }\end{array}$ & $\begin{array}{c}\text { WW } \\
\text { ORCF101 }\end{array}$ \\
\hline Annual SW & 4 & 4 & $\begin{array}{l}\text { SW } \\
\text { Zak }\end{array}$ & $\begin{array}{l}\text { SW } \\
\text { Zak }\end{array}$ & $\begin{array}{c}\text { SW } \\
\text { Louise }\end{array}$ & $\begin{array}{l}\text { SW } \\
\text { Louise }\end{array}$ & $\begin{array}{c}\text { SW } \\
\text { Louise }\end{array}$ & $\begin{array}{c}\text { SW } \\
\text { Louise }\end{array}$ & $\begin{array}{c}\text { SW } \\
\text { Louise }\end{array}$ & $\begin{array}{c}\text { SW } \\
\text { Louise }\end{array}$ & $\begin{array}{c}\text { SW } \\
\text { Louise }\end{array}$ \\
\hline Annual SB & 5 & 5 & $\begin{array}{c}\text { SB } \\
\text { Camas }\end{array}$ & $\begin{array}{c}\text { SB } \\
\text { Camas }\end{array}$ & $\begin{array}{c}\text { SB } \\
\text { Camas }\end{array}$ & $\begin{array}{c}\text { SB } \\
\text { Camas }\end{array}$ & $\begin{array}{c}\text { SB } \\
\text { Haxby }\end{array}$ & $\begin{array}{c}\text { SB } \\
\text { Camas }\end{array}$ & $\begin{array}{c}\text { SB } \\
\text { Camas }\end{array}$ & $\begin{array}{c}\text { SB } \\
\text { Camas }\end{array}$ & $\begin{array}{c}\text { SB } \\
\text { Camas }\end{array}$ \\
\hline \multirow[t]{3}{*}{ WW/SB/ChF } & 6 & $6 \mathrm{~A}$ & $\begin{array}{l}\text { WW } \\
\text { Tubbs }\end{array}$ & $\begin{array}{c}\text { SB } \\
\text { Camas }\end{array}$ & $\mathrm{ChF}$ & $\begin{array}{c}\text { WW } \\
\text { ORCF101 }\end{array}$ & $\begin{array}{c}\text { SB } \\
\text { Haxby }\end{array}$ & $\mathrm{ChF}$ & $\begin{array}{c}\text { WW } \\
\text { ORCF102 }\end{array}$ & $\begin{array}{c}\text { SB } \\
\text { Camas }\end{array}$ & $\mathrm{ChF}$ \\
\hline & & $6 \mathrm{~B}$ & $\begin{array}{c}\text { SB } \\
\text { Camas }\end{array}$ & $\mathrm{ChF}$ & $\begin{array}{c}\text { WW } \\
\text { Stephens }\end{array}$ & $\begin{array}{c}\text { SB } \\
\text { Camas }\end{array}$ & $\mathrm{ChF}$ & $\begin{array}{c}\text { WW } \\
\text { Tubbs'06 }\end{array}$ & $\begin{array}{c}\text { SB } \\
\text { Camas }\end{array}$ & $\mathrm{ChF}$ & $\begin{array}{c}\text { WW } \\
\text { ORCF101 }\end{array}$ \\
\hline & & $6 \mathrm{C}$ & $\mathrm{ChF}$ & $\begin{array}{l}\text { WW } \\
\text { Tubbs }\end{array}$ & $\begin{array}{c}\text { SB } \\
\text { Camas }\end{array}$ & $\mathrm{ChF}$ & $\begin{array}{c}\text { WW } \\
\text { ORCF101 }\end{array}$ & $\begin{array}{c}\text { SB } \\
\text { Camas }\end{array}$ & $\mathrm{ChF}$ & $\begin{array}{c}\text { WW } \\
\text { ORCF101 }\end{array}$ & $\begin{array}{c}\text { SB } \\
\text { Camas }\end{array}$ \\
\hline \multirow[t]{2}{*}{ WW/WP } & 7 & $7 \mathrm{~A}$ & $\begin{array}{l}\text { WW } \\
\text { Tubbs }\end{array}$ & $\begin{array}{l}\text { WP } \\
706\end{array}$ & $\begin{array}{c}\text { WW } \\
\text { Stephens }\end{array}$ & $\begin{array}{c}\text { WP } \\
\text { Specter }\end{array}$ & $\begin{array}{c}\text { WW } \\
\text { ORCF101 }\end{array}$ & $\begin{array}{c}\text { WP } \\
\text { Austrian }\end{array}$ & $\begin{array}{c}\text { WW } \\
\text { ORCF102 }\end{array}$ & $\begin{array}{c}\text { WP } \\
\text { Windham }\end{array}$ & $\begin{array}{c}\text { WW } \\
\text { ORCF101 }\end{array}$ \\
\hline & & $7 \mathrm{~B}$ & $\begin{array}{c}\text { WP } \\
\text { Austrian }\end{array}$ & $\begin{array}{l}\text { WW } \\
\text { Tubbs }\end{array}$ & $\begin{array}{c}\text { WP } \\
\text { Specter }\end{array}$ & $\begin{array}{c}\text { WW } \\
\text { ORCF101 }\end{array}$ & $\begin{array}{c}\text { WP/SP } \\
\text { Universal }\end{array}$ & $\begin{array}{c}\text { WW } \\
\text { Tubbs`06 }\end{array}$ & $\begin{array}{c}\text { WP/SP } \\
\text { Universal }\end{array}$ & $\begin{array}{c}\text { WW } \\
\text { ORCF101 }\end{array}$ & $\begin{array}{c}\text { WP } \\
\text { Windham }\end{array}$ \\
\hline Flex crops & 8 & $8 \mathrm{~A}$ & $\begin{array}{c}\text { SB } \\
\text { Camas } \\
\text { SW } \\
\text { Zak }\end{array}$ & $\begin{array}{c}\text { SW } \\
\text { Zak } \\
\text { SB } \\
\text { Camas }\end{array}$ & $\begin{array}{c}\text { SM } \\
\text { Tilney } \\
\text { ChF }\end{array}$ & $\begin{array}{c}\text { SW } \\
\text { Louise } \\
\text { WW } \\
\text { ORCF101 }\end{array}$ & $\begin{array}{c}\text { SC } \\
\text { Calina } \\
\text { SP } \\
\text { Universal }\end{array}$ & $\begin{array}{c}\text { SP } \\
\text { Universal } \\
\text { SW } \\
\text { Louise }\end{array}$ & $\begin{array}{c}\text { SW } \\
\text { Louise } \\
\text { SP } \\
\text { Universal }\end{array}$ & $\begin{array}{c}\text { SC } \\
\text { Calina } \\
\text { SW } \\
\text { Louise }\end{array}$ & $\begin{array}{c}\text { WW } \\
\text { ORCF101 } \\
\text { SC } \\
\text { Calina }\end{array}$ \\
\hline \multicolumn{12}{|c|}{ 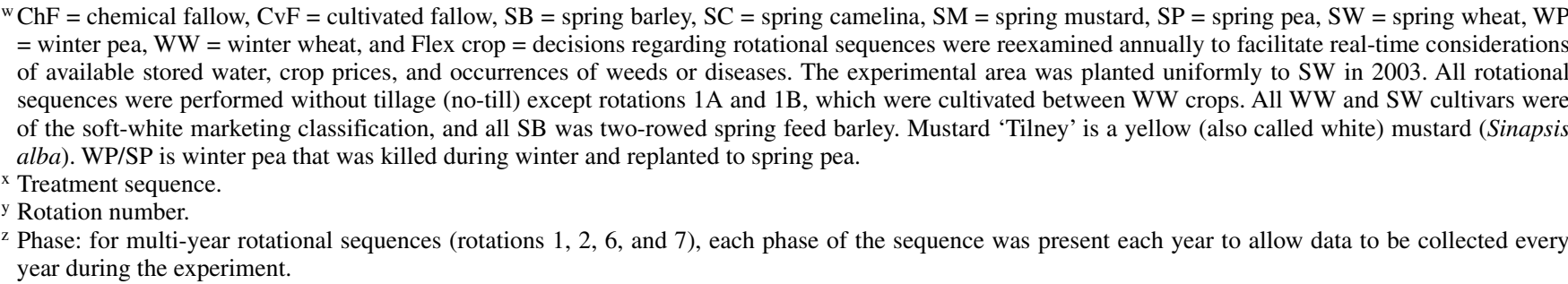 } \\
\hline
\end{tabular}


sample was submitted to Western Laboratories for extractions and reporting of total Pratylenchus spp., as described above. Another 500 -g subsample was dried in an oven at $40^{\circ} \mathrm{C}$ for $48 \mathrm{~h}$ and submitted to the Root Disease Testing Service (RDTS), South Australia Research and Development Institute, Adelaide, Australia. The RDTS extracted DNA from soil using the PreDicta B analysis system (20; http://www.sardi.sa.gov.au/products_and_services/ entomology/diagnostic_service/predicta_b) and reported numbers of individual species of Pratylenchus. Data included numbers of $P$. neglectus, $P$. thornei, P. teres, Heterodera avenae, and Ditylenchus dipsaci per gram of soil. Of these species, only $P$. neglectus, $P$. thornei, and $H$. avenae have been previously detected at the experimental site and only $P$. neglectus had been detected in densities sufficiently high to have been considered economically important at this site $(44,46)$.

Columbia Basin Agricultural Research Center Laboratory. Suspensions of nematodes extracted and identified to genus level by Western Laboratories were returned to our laboratory at the Columbia Basin Agricultural Research Center for identification of Pratylenchus spp. in four to five randomly selected plots during each of the last 3 years of the experiment. The authors used PCR (61) and morphological characteristics and measurements (11) to identify these species.

During 2012, we also extracted nematodes from each replicate of rotation 3 (annual winter wheat) and rotation 4 (annual spring wheat) using the Whitehead tray method (59) for extractions of nematodes from a 200-g subsample of the same samples submitted for extraction at Western Laboratories and the RDTS. Numbers and identities of $P$. neglectus and $P$. thornei were determined using morphological characteristics. Data are presented as means of counts from three separate aliquots taken from each of three replicates for the two treatments.

Statistical analysis. Nematode data were transformed using $\ln (x$ +1 ) to normalize population estimates prior to statistical analysis (27). Long-term effects of rotations were evaluated by grouping nematode density data across years for analysis, with years and rotation treatments or crops as main effect variables and replicates as blocks. The densities of Pratylenchus spp. during the spring following the growth of each crop were also analyzed. Analyses were performed using the generalized linear mixed-model procedure (PROC GLIMMIX) in Statistical Analysis System (SAS, version 9.2; SAS Institute), which does not require a normal distribution of data. When main effects for treatments were significant at $\alpha<0.05$, means were separated using the Tukey's honestly significant difference test if numbers of observations were uniform among treatments or by the least significant difference test when numbers of observations differed among treatments. Logarithmic means of nematode density were back transformed to real numbers for presentation in this article. Regression analysis was used to evaluate associations between

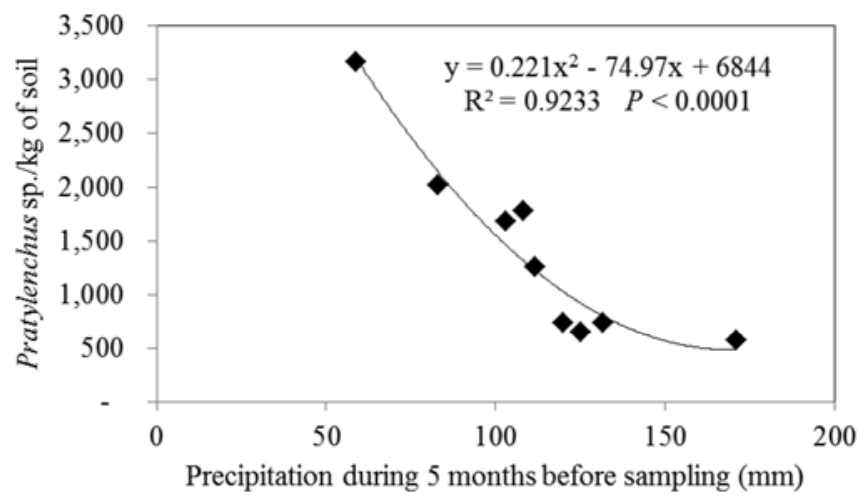

Fig. 1. Relationship between the mean density of Pratylenchus spp. in 42 plots during each of 9 years (2004 to 2012) and the over-winter and early-spring precipitation (November to March) that preceded collection of soil samples during those years. precipitation and nematode density and between nematode densities determined by traditional extraction methods and DNA extraction during 2012.

\section{Results}

The only plant-parasitic nematodes capable of affecting plant health in this experiment were $P$. neglectus and $P$. thornei. Densities of these species differed among rotations and were evaluated annually. Other plant parasites that were detected infrequently, were always in low numbers, and occurred without any relationship to crop treatment included species of Criconemoides, Geocenamus, Helicotylenchus, Heterodera, Meloidogyne, Paratylenchus, and Tylenchorhynchus. Analyses of results were restricted to species of Pratylenchus.

Annual precipitation over the 9-year experimental period averaged $289 \mathrm{~mm}$ and ranged from $181 \mathrm{~mm}$ in 2008 (driest year) to $396 \mathrm{~mm}$ in 2010 (wettest year). Precipitation during the over-winter and early-spring period (November to March) was considered more indicative of potential nematode activity. Precipitation during this presampling period averaged $112 \mathrm{~mm}$ over the 9-year period, including two particularly dry 5-month periods (83 and $59 \mathrm{~mm}$ in 2007 and 2008, respectively) and three comparatively wet 5-month periods $(125,171$, and $132 \mathrm{~mm}$ in 2004, 2010, and 2012, respectively). When the Pratylenchus spp. density for all 42 plots sampled each year were averaged and plotted against the amount of precipitation from November through March during that year, there was a significantly inverse relationship between the nematode density and the precipitation (Fig. 1).

Main rotations. Main effects were significant $(\alpha<0.0001)$ for year, rotation, and the year-rotation interaction. Mean density of Pratylenchus spp. over the 9-year sampling period for each rotation (Table 2) was significantly higher in annual spring wheat than for five other rotations: annual spring barley, the 3-year rotation, the flexible cropping treatment, and the direct-seed winter wheat rotations with either winter pea or chemical fallow. The density did not differ between the direct-seed and the cultivated rotations of winter wheat with fallow, or between the direct-seed rotations of winter wheat with fallow or with winter pea. An evaluation of year-rotation interactions was not helpful for interpreting further differences among the data.

Rotation phases. To identify possible changes in Pratylenchus spp. density within phases of individual rotations, analyses were performed for each phase of the main rotations after removing data for the first year (2004) in which all crops and treatments followed spring wheat. Data were also removed for the flexible cropping sequence (rotation 8) due to the irregular pattern of crops planted and to the occurrence of only three repetitions of several crops during the last 8 years of the experiment. Data for the annual crop

Table 2. Density of Pratylenchus spp. in the upper $30 \mathrm{~cm}$ of soil during the spring for eight cropping systems during a 9-year interval (2004 to 2012) at Moro, OR

\begin{tabular}{|c|c|c|c|}
\hline Rotation $^{w}$ & Rotation name $^{x}$ & Nematodes $/ \mathrm{kg}^{\mathrm{y}}$ & $n^{\mathbf{z}}$ \\
\hline 4 & Annual SW & $3,017 \mathrm{a}$ & 27 \\
\hline 3 & Annual WW & $2,305 a b$ & 27 \\
\hline 1 & $\mathrm{WW} / \mathrm{CvF}$ & $1,653 \mathrm{ab}$ & 54 \\
\hline 7 & WW/WP & $1,486 \mathrm{~b}$ & 54 \\
\hline 2 & WW/ChF & $1,291 \mathrm{~b}$ & 54 \\
\hline 8 & Flex crop & $1,242 \mathrm{~b}$ & 54 \\
\hline 6 & WW/SB/ChF & $676 \mathrm{c}$ & 81 \\
\hline 5 & Annual SB & $352 \mathrm{c}$ & 27 \\
\hline
\end{tabular}

${ }^{\mathrm{w}}$ Crops and management treatments are shown in Table $1 . P<0.01$.

${ }^{x} \mathrm{ChF}=$ chemical fallow, $\mathrm{CvF}=$ cultivated fallow, $\mathrm{SB}=$ spring barley, $\mathrm{SW}$ $=$ spring wheat, $\mathrm{WP}=$ winter pea, $\mathrm{WW}=$ winter wheat, Flex crop $=$ variable crop sequences over years.

y Pratylenchus nematodes per kilogram of soil. Data are back-transformed means of the $\ln (x+1)$ transformation used for analysis. Numbers followed by the same letter are not significantly different at $\alpha=0.05$ according to the least significant difference test for non-equal treatments.

${ }^{\mathrm{z}}$ Number of observations available during the 9-year interval. 
sequences (rotations 3, 4, and 5) were also deleted because those data were presented in Table 2.

Nematode densities following specific 2- or 3-year crop or fallow treatment sequences in rotations $1,2,6$, and 7 are presented in Figure 2. Main effects were significant $(\alpha<0.0001)$ for year, rotation, and the year-rotation interaction. It is important to note that Figure 3 shows nematode densities during the spring following the crop indicated within each rotational sequence. For instance, in the 2-year rotations of winter wheat and fallow, the nematode density shown is for the spring following winter wheat, which is the current fallow phase of that rotation. Therefore, the nematode density was higher during the fallow phase than during the current winter wheat phase, because the winter wheat was still small when sampling occurred during the spring following a fallow phase. The mean density of Pratylenchus spp. over 8 years was greater $(\alpha=$ $0.02)$ in cultivated fallow $(2,481$ nematodes $/ \mathrm{kg}$ of soil $)$ than in chemical fallow (1,456 nematodes/kg of soil). For individual years, the density was significantly greater $(\alpha=0.02)$ in cultivated than chemical fallow during 2005 and 2006, years of "dry" and "normal" precipitation, respectively. Numerical differences $(\alpha>$ 0.05) also occurred during 2007 (dry year) and 2009 (normal precipitation). No numerical differences among these treatments occurred during 2008 (a dry year) or during 2004, 2010, and 2012 (wetter-than-normal spring-time precipitation).

Because the nematode density was comparable in the young winter wheat crops following years of cultivated or chemical fallow, it appeared that the density of Pratylenchus spp. declined more rapidly in cultivated than in chemical fallow. In the cultivated fallow of rotation 1, the density of Pratylenchus spp. diminished by about 50\% during the 14-month fallow period. The mean density of nematodes decreased from 2,481 Pratylenchus nematodes $/ \mathrm{kg}$ of soil in fallow during the spring following the winter wheat crop to 1,278 nematodes $/ \mathrm{kg}$ of soil during the spring of the winter wheat crop that had been planted 6 months earlier, following 14 months of fallow. In contrast, in the direct-seed treatment (rotation 2), the decrease in mean density of Pratylenchus spp. was $21 \%$ during the same time period; from 1,456 to 1,151 Pratylenchus nematodes $/ \mathrm{kg}$ of soil. When the density of Pratylenchus spp. was evaluated for the current winter wheat crops following chemical or cultivated fallows in rotations 1 and 2 , the difference was not significant across years or during individual years.

In the 3-year direct-seed rotation (rotation 6), the density of Pratylenchus spp. was very low (418 nematodes $/ \mathrm{kg}$ of soil) at the

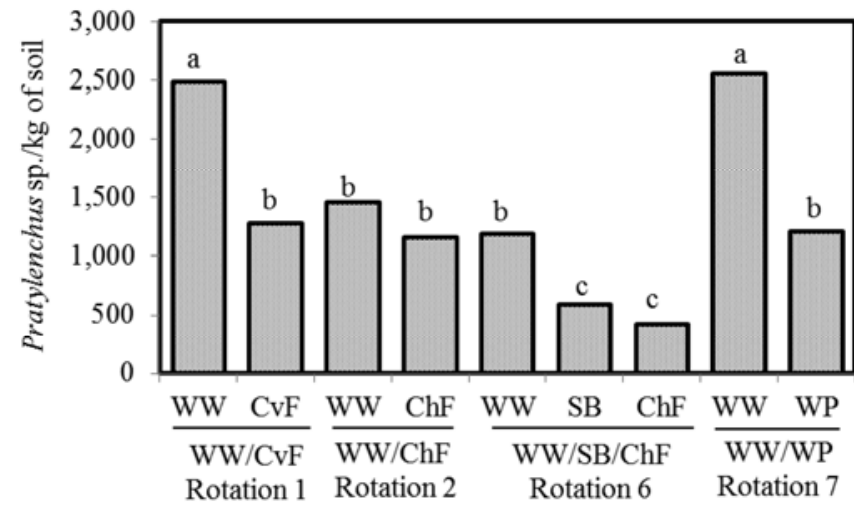

Fig. 2. Density of Pratylenchus spp. in the upper $30 \mathrm{~cm}$ of soil during the spring following a specific crop or fallow treatment in different phases of 2- and 3-year rotations during the final 8 years (2005 to 2012) at Moro, OR. Crops and management treatments are shown in Table 1. WW = winter wheat, $\mathrm{CvF}=$ cultivated fallow, $\mathrm{ChF}=$ chemical fallow, $\mathrm{SB}=$ spring barley, $\mathrm{WP}=$ winter pea. Treatments (crop or fallow) in each plot alternate annually in the sequence shown for each rotation. Bars $(n=24)$ having the same letter do not differ significantly at $\alpha=0.05$ according to the least significant difference test. Because sampling was during the spring when WW and WP were 5 months old but still small, when SB had recently been planted, and before CvF had been cultivated, the data for each treatment phase reflects the influence of the previous crop or treatment in each rotation (e.g., data for WW in rotation 1 is currently in CvF, reflecting the influence of the preceding WW crop). time of sampling of young winter wheat (Fig. 3, ChF), was significantly higher when the spring barley was planted following winter wheat (1,190 nematodes/kg; Fig. 3, WW), and began diminishing again during the chemical fallow following the spring barley cycle (586 nematodes/kg; Fig. 3, SB). This cycling indicated that winter wheat led to amplification of the Pratylenchus spp. density and that it decreased during the years when a poor host (barley) was present and was further diminished during chemical fallow. Only a single year of winter wheat was required to amplify densities of Pratylenchus spp. to values comparable with those following winter wheat in the 2-year rotation with chemical fallow.

In the winter wheat/winter pea rotation (rotation 7), the density of Pratylenchus spp. following winter pea was similar to the density detected in comparable phases of the winter wheat rotation with chemical fallow (rotation 2). However, it was of particular interest that there was a numeric doubling of nematode density in the direct-drill winter wheat that followed winter pea, as compared with direct-drill winter wheat that followed chemical fallow.

Crop species. The influence of all crops was evaluated by analyzing data of Pratylenchus spp. density for 9 years on the basis of the crop during the previous year, without regard to the current crop. This analysis was for spring crops that were newly planted or winter crops that had been planted 6 months earlier but were still small following the winter months. The main effect of previous crop was significant at $\alpha<0.0001$. Densities of Pratylenchus spp.
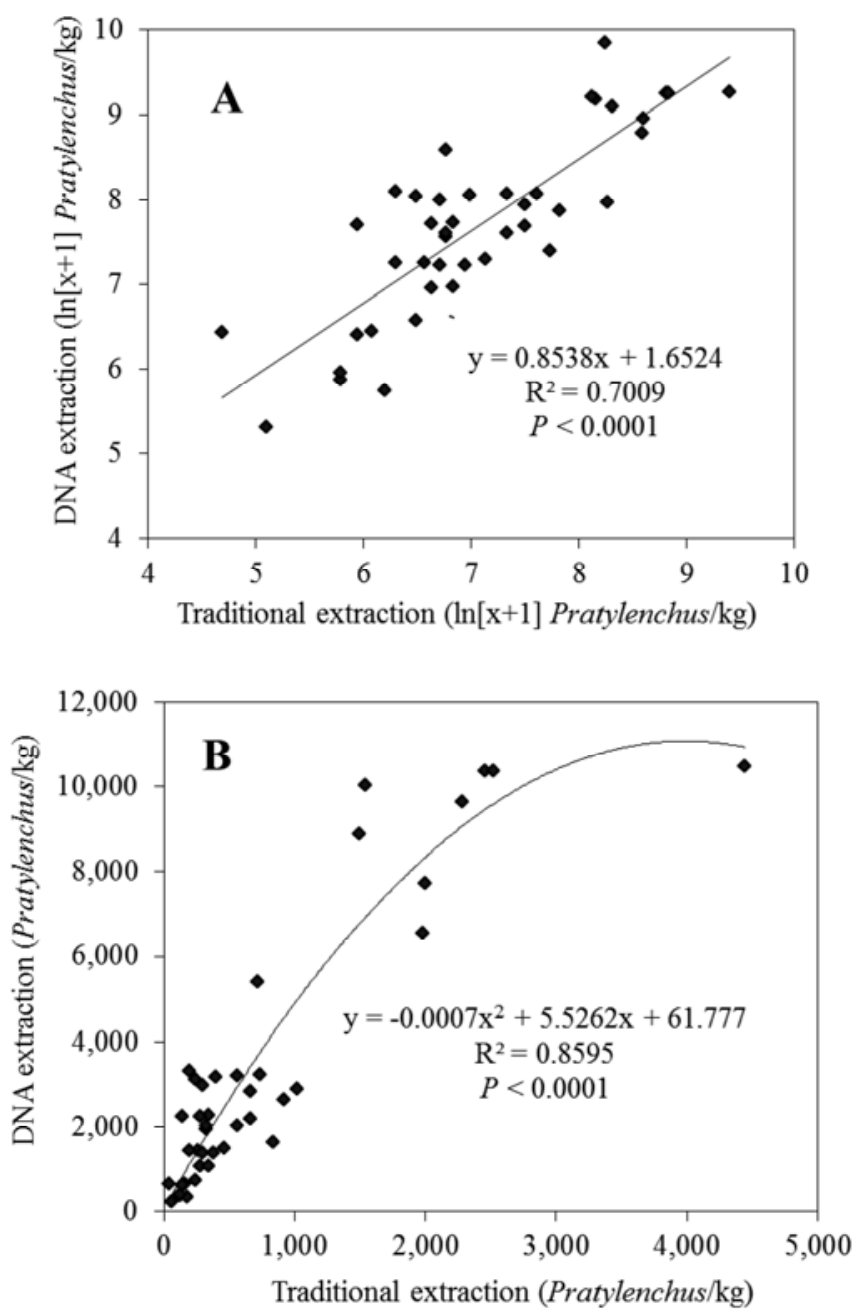

Fig. 3. Comparison of Pratylenchus spp. nematodes per kilogram of soil reported for 42 plots of the experiment at Moro, OR during 2012; data are based upon traditional physical extractions reported by Western Laboratories (Parma, ID) or upon real-time polymerase chain reaction on DNA from soil extracts using the PreDicta $B$ analysis reported by the Root Disease Testing Service (Adelaide, Australia). A, Natural logarithmic transformations $[\ln (x+1)]$ of data for 42 plots. B, Nematode densities reported by each lab for 41 of 42 plots. 
following crops of spring wheat, mustard, winter pea, and winter wheat were significantly greater than densities following camelina, spring barley, or spring pea (Table 3).

Species-specific nematode assays. Annual assessments of Pratylenchus spp. density were performed at Western Laboratories, which did not distinguish among individual species of Pratylenchus. During the final year of the experiment, the soil samples were uniformly mixed and subsamples were sent to both Western Laboratories and the RDTS. Additional soil was retained for use in our laboratory. The RDTS performs species-specific analyses on DNA extracted from soil. A strong correlation was revealed between densities of total Pratylenchus nematodes per kilogram of soil reported by the two labs (Fig. 3A), with greater densities reported from DNA extractions than from a traditional extraction and identification method. Estimates of density were approximately four times greater from DNA extraction than from traditional extraction when the density reported by the traditional method was less than about 2,500 Pratylenchus nematodes/kg of soil (Fig. 3B). Data for one replicate of the annual winter wheat treatment (rotation 3) was not included in Figure 3B. The soil was very dry in the annual winter wheat plots during the spring and the soil probes had to be vigorously hammered into the soil to collect samples of a depth equal to other treatments. Estimates of nematode density from DNA extracts from one particularly dry replicate had a reported density 13 times greater than was indicated using traditional extraction and identification procedures (data not reported), suggesting that intensive fracturing of soil while collecting soil from that plot likely caused an underestimate of Pratylenchus spp. when the density was assessed using a traditional method.

The species-specific DNA data (Table 4) indicated that winter wheat had a greater density of $P$. neglectus and that spring wheat had a greater density of $P$. thornei. These trends were relatively consistent in the annual rotations (rotations 3 and 4), in the 2-year rotations of winter wheat with fallow (rotations 1 and 2) or with winter pea (rotation 7), in the 3-year rotation that includes winter wheat as one of the two crops (rotation 6), and in the flexible cropping decision treatments (rotation 8). It was notable that, in rotation 7, there was a greater inoculum density of P. neglectus when the current crop was winter wheat and a greater inoculum density of $P$. thornei when the current crop was winter pea, each reflecting the influence of the crop during the previous year, yet the density of generic Pratylenchus spp. was equivalent in each phase of the rotation (Table 4).

Because the DNA assays revealed an apparent selection of Pratylenchus spp. by different cropping systems, we reevaluated that possibility by using the Whitehead tray extraction method and morphological identification. We used additional subsamples from soil collected from three plots each of annual winter wheat and annual spring wheat treatments (rotations 3 and 4) that had already been examined by the RDTS and by Western Laboratories during 2012. Data for the Whitehead-based and DNA-based assays were

Table 3. Density of Pratylenchus spp. in the upper $30 \mathrm{~cm}$ of soil during the spring following production of the indicated crop during a 9-year interval (2004 to 2012) in the cropping systems experiment at Moro, OR

\begin{tabular}{lcr}
\hline Previous crop or treatment $^{\mathbf{x}}$ & ${\text { Nematodes } / \mathbf{k g}^{\mathbf{y}}}$ & $\boldsymbol{n}^{\mathbf{z}}$ \\
\hline Spring wheat & $2,873 \mathrm{a}$ & 42 \\
Mustard & $2,791 \mathrm{ab}$ & 3 \\
Winter pea & $2,269 \mathrm{ab}$ & 18 \\
Winter wheat & $1,965 \mathrm{~b}$ & 123 \\
Camelina & $659 \mathrm{c}$ & 6 \\
Spring barley & $537 \mathrm{c}$ & 54 \\
Spring pea & $376 \mathrm{c}$ & 15 \\
\hline
\end{tabular}

${ }^{x}$ Crops are shown in Table 1. $P<0.01$.

y Pratylenchus nematodes per kilogram of soil. Data are back-transformed means of the $\ln (x+1)$ transformation used for analysis. Numbers followed by the same letter within a column are not significantly different at $\alpha=0.05$ according to the least significant difference test for non-equal treatments.

${ }^{\mathrm{z}}$ Number of observations available during the 9-year interval. consistent in that both indicated a significantly $(\alpha<0.05)$ greater prevalence of $P$. neglectus than $P$. thornei in winter wheat compared with spring wheat (Table 5). The DNA-based assay revealed a significantly greater density of $P$. thornei than $P$. neglectus in spring wheat. Only the elutriation method revealed a significant difference in total Pratylenchus spp. density between spring and winter wheat. Data were highly correlated $(\alpha<0.01)$ between our lab and the RDTS for densities of $P$. neglectus $\left(R^{2}=0.85\right)$ and $P$. thornei $\left(R^{2}=0.88\right)$. Densities reported for total Pratylenchus nematodes per kilogram of soil in these six plots were not significantly $(\alpha>0.05)$ correlated between labs; our lab versus RDTL $\left(R^{2}=0.17\right)$, our lab versus Western Lab $\left(R^{2}=0.25\right)$, and RDTL versus Western Lab $\left(R^{2}=0.11\right)$.

\section{Discussion}

We previously reported relationships between $P$. neglectus density and grain yield during the first 5 years of this long-term experiment (41). We reported an increasing prevalence of $P$. neglectus as intensity of wheat was increased, a high nematode density following crops of mustard or winter pea, a low density following spring barley and spring pea, a lack of influence of tillage (chemical versus cultivated fallow) on nematode density, an inverse relationship between yield of winter wheat and in-crop density of $P$. neglectus during the spring, and a reduced capacity of wheat roots to extract water from the soil profile in plots with the highest densities of $P$. neglectus.

In this report for all 9 years of the experiment, our results support our earlier observations. Moreover, we have now also demonstrated that (i) the distribution of two Pratylenchus spp. in this experiment was far more complex than previously understood, (ii) apparent Pratylenchus spp. density was significantly correlated ( $\alpha$ $<0.01)$ and generally higher when based upon extraction of DNA from soil than when based upon a traditional extraction and identification method, (iii) sampling very dry soil sometimes provided a strong underestimate of Pratylenchus spp. density when using a traditional extraction method, (iv) there was an inverse relationship $(\alpha<0.01)$ between density of Pratylenchus spp. in the upper soil profile and the amount of precipitation during the months preceding the collection of soil samples, and (v) camelina was a poor host for Pratylenchus spp.

Previously, we reported a predominance of $P$. neglectus in this experiment (41). We reported that $P$. thornei was also present but occurred at very low densities. Those observations were based upon periodic determinations of species in a few selected treatments, typically of winter wheat. During the last year of the study, while employing real-time PCR to assess nematode densities, we found that there was much more $P$. thornei in certain treatments than had been previously understood. Therefore, the distribution of these two Pratylenchus spp. in this experiment was complex. In particular, winter wheat promoted higher densities of $P$. neglectus than $P$. thornei and the reverse was true for spring wheat. It is unknown whether the differential selection of Pratylenchus spp. in this experiment was associated with undetermined differences among cultivars of winter and spring wheat or whether it may be associated with different growth habits that differentially favor one species over another. More research is required to validate and to fully understand this observation because wheat cultivars have important differences in their ability to allow one or another of these species to reproduce $(13,34-37,50,52)$. Pacific Northwest wheat cultivars also differ in their ability to tolerate invasion by these species (40). For instance, the spring wheat 'Louise' which was planted in our experiment has been shown to be moderately intolerant to invasion by both $P$. neglectus and $P$. thornei (40). Sheedy et al. (35) reported that $P$. thornei reproduced very effectively on Louise, which was among the most susceptible of spring wheat cultivars, and twice or three times as effectively as on 'Alpowa' spring wheat or 'Camas' barley, respectively. In another study, $P$. thornei reproduced three times more effectively on Alpowa than on Camas (38). Sheedy et al. (33) also showed that Alpowa was much more favorable for reproduction of $P$. thornei 
than of $P$. neglectus. Similar differences occur among cultivars of winter wheat. Sheedy et al. (36) reported that $P$. thornei reproduced twice as effectively on 'Tubbs' and 'Tubbs '06' than on 'ORCF 102', and that 'ORCF 101' was intermediate. Sheedy et al. (37) showed that $P$. neglectus reproduced prolifically on ORCF 102 and ORCF 101 and only slightly less on Tubbs and Tubbs '06. Compared with winter wheat cultivars used in our experiment, popular cultivars such as 'Stephens' and 'Madsen' were much poorer hosts of P. neglectus but very good to excellent hosts of $P$. thornei $(36,37)$. The choice of wheat cultivar will clearly have an impact on the density and dominance of these two species of Pratylenchus in Pacific Northwest fields. This aspect of management for Pratylenchus spp. should be given greater consideration for minimizing the level of risk to future plantings of intolerant cultivars or crop species.

Densities of Pratylenchus spp. reported from a lab that extracted DNA from soil and identified species by using real-time PCR was strongly correlated $\left(R^{2}=0.70, \alpha<0.01\right)$ with densities reported by a lab that used traditional elutriation-based extractions and morphological identifications. However, the apparent density reported by the DNA-based method was often about four times greater than for the traditional elutriation method. This discrepancy appeared to diminish as the density based upon traditional extractions became elevated above about 3,000 Pratylenchus nematodes $/ \mathrm{kg}$ of soil. The soils of various treatments in our experiment differed in moisture content at the time of sampling. Data from the RDTS would have included DNA from all nematode stages, including eggs, whereas data from Western Laboratories was based upon morphologically identifiable juvenile and adult stages. Eggs survive in an anhydrobiotic state in dry soils (5) and contribute to DNA extracted for evaluation by real-time PCR (18) but, compared with other life stages, are not easily or commonly detected when nematodes are extracted and identified using traditional methods. This likely con-

Table 4. Density of Pratylenchus neglectus and P. thornei in the upper $30 \mathrm{~cm}$ of soil during the spring for 14 rotational phases of eight main cropping systems; back-transformed means for each rotation during the final year (2012) at Moro, OR

\begin{tabular}{|c|c|c|c|c|c|c|c|}
\hline \multirow[b]{3}{*}{$\mathbf{R N}^{\mathbf{y}}$} & \multirow[b]{3}{*}{ Treatment $^{\mathrm{z}}$} & & & \multicolumn{4}{|c|}{ Pratylenchus nematodes per kilogram of soil ${ }^{w}$} \\
\hline & & \multicolumn{2}{|c|}{ Crop or treatment $\mathbf{t}^{\mathrm{x}}$} & \multicolumn{3}{|c|}{ Root Disease Testing Service } & \multirow{2}{*}{$\begin{array}{c}\text { Western } \\
\text { Total }\end{array}$} \\
\hline & & Current & Previous & P. neglectus & P. thornei & Total & \\
\hline 1 & $\mathrm{WW} / \mathrm{CvF}$ & WW & $\mathrm{CvF}$ & $1,790 \pm 387 \mathrm{bcd}$ & $331 \pm 154 \mathrm{c}$ & $2,121 \pm 363 \mathrm{~cd}$ & $1,526 \pm 350 \mathrm{c}$ \\
\hline 1 & $\mathrm{WW} / \mathrm{CvF}$ & $\mathrm{CvF}$ & WW & $1,996 \pm 278 b c$ & $774 \pm 419 b c$ & $2,769 \pm 267 \mathrm{~cd}$ & $1,757 \pm 330 \mathrm{c}$ \\
\hline 2 & $\mathrm{WW} / \mathrm{ChF}$ & WW & $\mathrm{ChF}$ & $1,178 \pm 179$ cde & $524 \pm 170 \mathrm{bc}$ & $1,702 \pm 257 \mathrm{~cd}$ & $694 \pm 122 \mathrm{de}$ \\
\hline 2 & $\mathrm{WW} / \mathrm{ChF}$ & $\mathrm{ChF}$ & WW & $1,163 \pm 642 \mathrm{cde}$ & $1,228 \pm 520 b c$ & $2,391 \pm 539 \mathrm{~cd}$ & $1,731 \pm 259 c$ \\
\hline 3 & Annual WW & WW & WW & $10,913 \pm 2,402 \mathrm{a}$ & $1.874 \pm 609 \mathrm{~b}$ & $12,787 \pm 2,983 \mathrm{a}$ & $3,546 \pm 481 \mathrm{~b}$ \\
\hline 4 & Annual SW & SW & SW & $1,110 \pm 542 \mathrm{cde}$ & $7,959 \pm 1,814 \mathrm{a}$ & $9,066 \pm 1,277 \mathrm{~b}$ & $6,269 \pm 571 \mathrm{a}$ \\
\hline 5 & Annual SB & SB & SB & $316 \pm 22 \mathrm{e}$ & $35 \pm 35 c$ & $351 \pm 22 \mathrm{~d}$ & $372 \pm 20 \mathrm{de}$ \\
\hline 6 & $\mathrm{WW} / \mathrm{SB} / \mathrm{ChF}$ & WW & SB & $743 \pm 299 \mathrm{de}$ & $276 \pm 245 c$ & $1,019 \pm 214 \mathrm{~cd}$ & $645 \pm 44 \mathrm{de}$ \\
\hline 6 & $\mathrm{WW} / \mathrm{SB} / \mathrm{ChF}$ & SB & $\mathrm{ChF}$ & $183 \pm 74 \mathrm{e}$ & $295 \pm 162 \mathrm{c}$ & $478 \pm 139 d$ & $188 \pm 31 \mathrm{e}$ \\
\hline 6 & $\mathrm{WW} / \mathrm{SB} / \mathrm{ChF}$ & $\mathrm{ChF}$ & WW & $1,002 \pm 254 \mathrm{cde}$ & $566 \pm 189 \mathrm{bc}$ & $1,568 \pm 426 \mathrm{~cd}$ & $951 \pm 96 \mathrm{de}$ \\
\hline 7 & WW/WP & WW & WP & $2,460 \pm 275 b$ & $607 \pm 276 b c$ & $3,067 \pm 59 \mathrm{c}$ & $832 \pm 76 \mathrm{de}$ \\
\hline 7 & WW/WP & WP & WW & $1,356 \pm 873$ bcde & $1,909 \pm 188 \mathrm{~b}$ & $3,264 \pm 1,061 \mathrm{c}$ & $1,058 \pm 121 \mathrm{~cd}$ \\
\hline 8 & Flex crop & WW & Cam & $418 \pm 42 \mathrm{e}$ & $1,503 \pm 734 b c$ & $1,921 \pm 694 \mathrm{~cd}$ & $648 \pm 53 \mathrm{de}$ \\
\hline \multirow[t]{3}{*}{8} & Flex crop & Cam & SW & $1,006 \pm 40 \mathrm{c} \mathrm{de}$ & $7,997 \pm 823 \mathrm{a}$ & $9,003 \pm 803 b$ & $6,443 \pm 908 a$ \\
\hline & Mean & $\ldots$ & $\ldots$ & 1,831 & 1,848 & 3,679 & 1,903 \\
\hline & $P>F$ & $\cdots$ & $\cdots$ & $<0.01$ & $<0.01$ & $<0.01$ & $<0.01$ \\
\hline
\end{tabular}

${ }^{w}$ Densities of Pratylenchus spp. per kilogram of soil were based upon DNA extractions using the PreDicta B analysis procedure at the Root Disease Testing Service, Adelaide, Australia, or upon traditional physical extraction procedures at Western Laboratories, Parma, ID (Western). Numbers followed by the same letter within a column and within a group are not significantly different at $\alpha=0.05$ according to the Tukey's honestly significant difference test.

$\times \mathrm{Cam}=$ camelina, $\mathrm{ChF}=$ chemical fallow, $\mathrm{CvF}=$ cultivated fallow, $\mathrm{SB}=$ spring barley, $\mathrm{SW}=$ spring wheat, $\mathrm{WP}=$ winter pea, and $\mathrm{WW}=$ winter wheat.

${ }^{\mathrm{y}}$ Rotation number. Crops and treatments in each rotation are shown in Table 1.

${ }^{\mathrm{z}}$ Treatment sequence. Flex crop $=$ variable crop sequences over years.

Table 5. Relationship between densities of Pratylenchus neglectus, $P$. thornei, and total Pratylenchus spp. using three different methods to extract nematodes from soil collected from annual winter wheat (rotation 3) and annual spring wheat (rotation 4) during 2012 in the long-term experiment at Moro, OR (mean \pm standard error of the mean $)^{x}$

\begin{tabular}{|c|c|c|c|c|}
\hline Nematodes and extraction method ${ }^{y}$ & Winter wheat & Spring wheat & $P>F$ & $\mathrm{~W} / \mathrm{S}$ ratio $^{\mathrm{z}}$ \\
\hline \multicolumn{5}{|l|}{ Total Pratylenchus nematodes $/ \mathrm{kg}$ of soil } \\
\hline Whitehead & $7,322 \pm 973$ & $8,936 \pm 2,204$ & 0.51 & 0.8 \\
\hline DNA & $12,787 \pm 2,983$ & $9,066 \pm 1,277$ & 0.28 & 1.4 \\
\hline Elutriation & $3,546 \pm 481 b$ & $6,269 \pm 571 \mathrm{a}$ & $<0.01$ & 0.6 \\
\hline \multicolumn{5}{|l|}{ P. neglectus nematodes $/ \mathrm{kg}$ of soil } \\
\hline Whitehead & $6,631 \pm 439 a$ & $1,747 \pm 706 b$ & 0.04 & 3.8 \\
\hline DNA & $10,913 \pm 2,402 \mathrm{a}$ & $1,110 \pm 542 b$ & 0.03 & 9.8 \\
\hline \multicolumn{5}{|l|}{ P. thornei nematodes/kg of soil } \\
\hline Whitehead & $1,691 \pm 541$ & $7,189 \pm 2,854$ & 0.19 & 0.2 \\
\hline DNA & $1,874 \pm 609 b$ & $7,959 \pm 1,814 \mathrm{a}$ & 0.05 & 0.2 \\
\hline \multicolumn{5}{|l|}{ P. neglectus/P. thornei ratio } \\
\hline Whitehead & $3.9 \pm 0.8 \mathrm{a}$ & $0.2 \pm 0.0 \mathrm{~b}$ & 0.04 & $\ldots$ \\
\hline DNA & $5.8 \pm 1.2 \mathrm{a}$ & $0.2 \pm 0.2 \mathrm{~b}$ & 0.03 & $\ldots$ \\
\hline
\end{tabular}

${ }^{x}$ Numbers followed by the same letter within a column and within a group are not significantly different at $\alpha=0.05$ according to the Tukey's honestly significant difference test.

y Subsamples of well-mixed soil from each of three replicates for each crop type were used to extract Pratylenchus spp. from soil. Whitehead $=200-\mathrm{g}$ subsamples were extracted using the Whitehead Tray method and nematodes were identified to species level based upon morphological characteristics at the author's laboratory at Pendleton, OR. DNA = DNA was extracted from 500-g subsamples of the aforementioned samples and nematode counts were derived from species-specific real-time polymerase chain reaction analyses and standard curves at the Root Disease Testing Service at Adelaide, Australia. Elutriation $=250-\mathrm{g}$ subsamples were extracted using an elutriation method and nematodes were identified to genus level based upon morphological characteristics at Western Laboratories at Parma, ID.

${ }^{\mathrm{z}}$ Winter wheat/spring wheat ratio. 
tributes to greater estimates of nematode density commonly encountered in real-time PCR assays than in traditional assays $(12,18,20,60)$. However, soil handling can also affect the vigor and integrity of nematodes extracted using traditional methods. Hollaway et al. (12) reported that the PreDicta B method using DNA extracted from soil, as used at the RDTS, was not influenced by soil water content at the time of sampling or of drying the soil after sampling. In dry soils, the DNA method revealed apparent densities of $P$. neglectus and $P$. thornei two to four times greater than were revealed by the Whitehead extraction method, which extracts mostly active nematodes. The differences between methods were minimal when extractions were made from the same soils that were sampled while wet. The Whitehead tray also extracted fewer Pratylenchus nematodes from soils that had been dried before storage (12). The magnitudes of reduction varied depending upon soil type and differences in soil moisture content. For very dry soils infested by $P$. neglectus and $P$. thornei, the DNA method revealed apparent nematode densities as much as eight times higher than were revealed by the Whitehead method.

One of the 42 data points used to construct Figure 3A was 13 times higher from the DNA extraction than from the traditional extraction and, therefore, was not included in Figure 3B. That datum point represented one replicate of the direct-seed annual winter wheat rotation, for which the soil was very dry and compact during the spring, and for which the soil probes had to be vigorously hammered into the soil to collect samples of a depth equal to other treatments. Collection of those three samples required as many as 20 jarring blows with a heavy hammer to the top of the sampling probe to attain an adequate sampling depth due to very dry soils and an impervious tillage pan. The resulting DNA analyses for one replicate indicated densities much higher than the approximately fourfold differences indicated in the other 41 plots. We suspect that cuticles of Pratylenchus spp. were ruptured at much greater frequency when probes were hammered into the soil than when the probes were manually pressed into soil without the use of a hammer. Taylor and Evans (49) reported that fewer Pratylenchus spp. could be extracted from dry soils relative to wet soils if the nematodes were physically impaired during sampling. Pratylenchus spp. survive dry periods in the anhydrobiotic state $(10,56)$, at which time they are brittle and more easily damaged. Sampling procedures that disrupt soil physical structure reduce the recovery of nematodes using traditional extraction methods (3). In our experiment, the hammer had also been used to sample soils during earlier years when some of the annual winter wheat plots were also hard and dry compared with plots of other treatments. It appears likely that Pratylenchus spp. densities were underestimated for annual winter wheat by the elutriation method during 2012 and were likely also underestimated during the very dry springs of 2007 and 2008. However, it is also possible that eggs were the most prevalent life stage in the driest soils sampled, making it difficult to distinguish between potential effects of physical injury to the anhydrobiotic vermiform stages and differences among proportions of life stages caused by differences in soil moisture.

We previously reported that higher numbers of Pratylenchus spp. were typically detected in fallow following wheat than during the spring of the winter wheat phase of the rotation (44). In this study, we found twice as many Pratylenchus spp. in the cultivated fallow $(2,481$ nematodes $/ \mathrm{kg}$ of soil) than in the chemical fallow $(1,456$ nematodes/kg of soil) treatment nearly 8 months after harvest. The density of nematodes in the young winter wheat crop following these fallow types were very similar: 1,456 versus 1,151 Pratylenchus nematodes $/ \mathrm{kg}$ of soil, respectively. Because wheat cultivars were the same for each phase of rotations 1 and 2, it was assumed that winter wheat in each treatment had a uniform capacity to amplify the density of these nematodes. The least numerical differences in nematode density between types of fallow occurred during 3 years of greater-than-normal spring-time precipitation. Numerical differences were generally greatest during years of normal spring-time precipitation or of drier-than-normal years. These differences suggest that either the rate of Pratylenchus nematode multiplication was lower in wheat following chemical fallow than cultivated fallow or the mortality was lower in cultivated soil than in no-till soil. Strausbaugh et al. (47) and Paulitz et al. (24) also reported that fewer Pratylenchus spp. were detected in chemical than in cultivated fallow but several reports indicated that densities of Pratylenchus spp. were greater in no-till than in cultivated fallows (22,51). Brmež et al. (4), Smiley et al. (42), and Smiley and Machado (41) did not detect a significant difference in density of Pratylenchus spp. between chemical and cultivated fallows. However, in our earlier report from the current experiment (41), we did detect nonsignificantly greater numbers of Pratylenchus nematodes at all depth intervals in cultivated than in chemical fallow, and the difference in density was greatest $(2,194$ versus 770 Pratylenchus nematodes $/ \mathrm{kg}$ of soil) in the $30-$ to $45-\mathrm{cm}$ depth interval. Moreover, in the profile depth sampling we reported earlier (41), the density of Pratylenchus spp. was very low ( $<200$ nematodes $/ \mathrm{kg}$ of soil) in the surface $15 \mathrm{~cm}$ and was much greater (about 3,000 nematodes $/ \mathrm{kg}$ of soil) in the 15 - to $30-\mathrm{cm}$ profile segment for each of the fallow systems. In this study, mechanical tillage operations in the cultivated fallow (rotation 1) never disrupted soil to a depth greater than $15 \mathrm{~cm}$. Data reported in this article were from samples routinely collected to a depth of $30 \mathrm{~cm}$, presumably reflecting mostly differences in Pratylenchus spp. densities in the 15- to 30-cm depth interval. Because seasonal differences in densities of Pratylenchus spp. in the two fallow management systems were detected in our experiment, it is likely that soil moisture, biological antagonism or predation $(5,51,55)$, or other factors differentially influenced the production or survival of Pratylenchus spp. in cultivated and uncultivated cropping systems. It is possible that biological interactions led to lower densities of Pratylenchus spp. in the uncultivated than cultivated fallow system because these contrasting systems often have important differences in microbial and faunal properties (48). However, it is also important to consider that most microbial differences among tillage systems occur within the tillage zone, which coincided with the depth at which we previously reported the lowest density of Pratylenchus spp. in this experiment (41).

We also noted that the density of Pratylenchus spp. declined more rapidly during cultivated $(50 \%)$ than chemical fallow $(21 \%)$ treatments. Likewise, Ornat et al. (22) reported that density of $P$. neglectus in the spring was reduced more by a combination of tillage and fallow than by fallow alone. It is possible that multiple tillage operations while the soil was very dry, as is standard practice for weed control in the semiarid Pacific Northwest (32), caused mechanical damage to bodies of Pratylenchus spp. while they were in the anhydrobiotic state $(10,49,56)$.

When the densities of Pratylenchus spp. were averaged over the 42 plots for each year of this experiment, there was an inverse relationship $\left(R^{2}=0.92 ; \alpha<0.01\right)$ between mean density of nematodes in the upper soil profile and the amount of precipitation that occurred during the 5 months (November through March) which preceded the time when soil samples were collected. However, this relationship did not occur when compared with amounts of precipitation during shorter time periods immediately preceding sampling, as for January through March $\left(R^{2}=0.32\right)$ or January through April $\left(R^{2}=0.47\right)$. There was also no relationship between densities of nematodes and precipitation over the winter wheat crop year (September through August; $R^{2}=0.08$ ). Although the cause for this relationship is not understood, we hypothesize that, compared with drier soil, the wetter soil during the winter months reduced survival of nematodes produced on crop roots the previous year. It is likely that the number of wetting and drying cycles during the winter months are fewer during the driest winters. If so, the drier periods during late autumn and early winter could favor longer periods of anhydrobiosis induced by cold temperature (56) or they could reduce mortality from parasitism (22). Another possibility is that drier autumn and winter months could be less favorable for vertical migration downward into the soil profile (44), or that soil temperatures were more buffered against surface freezing during wet winters. Further research will be required to understand this observation. 
Lowest densities of Pratylenchus spp. were detected following spring barley, spring pea, or camelina and higher densities occurred following winter wheat, spring wheat, spring yellow mustard, or winter pea. We are unaware of previous reports of the susceptibility of camelina cultivars to Pratylenchus spp. Barley is generally considered more tolerant and more resistant than wheat to P. neglectus and $P$. thornei $(40,50,55,57)$. Our findings are also in agreement with previous observations that Pratylenchus nematodes become more numerous as host-crop frequency is increased $(9,29)$. Smiley (40) and Smiley and Machado (41) reported a high density of $P$. neglectus following either yellow mustard or wheat. Field pea is considered resistant to P. neglectus in Australia (57) but has been associated with high populations of Pratylenchus spp. in the $\mathrm{Pa}-$ cific Northwest (28). The hosting abilities of field pea require further investigation, including the spring versus winter growth habit (e.g., the length of the growing season) and differences in cultivars or subspecies. In particular, the apparently greater multiplication of Pratylenchus spp. in winter wheat that followed winter pea than in winter wheat that followed chemical fallow requires further investigation because the greater amplification of nematode density following winter pea could be expected to substantially increase the level of root injury in subsequent plantings of intolerant winter wheat cultivars.

Camelina, barley, and spring pea were identified as poor hosts that could be used to reduce the density of $P$. neglectus and $P$. thor$n e i$ in heavily infested wheat fields, particularly if used in 3-year rotations. Selection of different Pratylenchus spp. by wheat of different growth habit or cultivar selection requires further study, pending development of cultivars with dual-species resistance. This finding also underscores the importance for developing speciesspecific diagnostic methods that can be easily and fully adopted into routine use by nematode diagnostic laboratories. This is critical in view of spring wheat cultivars that differentially vary in tolerance to P. neglectus or P. thornei (40).

\section{Acknowledgments}

This research was funded by an Oregon State University subcontract to the United States Department of Agriculture (USDA)-Agricultural Research Service (SCA number 58-5348-9-100) and by a grant from the USDA Cooperative State Research Education and Extension Service Solutions to Economic and Ecological Problems (STEEP), a Pacific Northwest Regional Research Program. We thank S. Easley, A. Thompson, J Sheedy, and A. Spence for technical assistance; and S. Petrie and farmers who served on the advisory committee for this long-term experiment.

\section{Literature Cited}

1. Bernard, E. C., and Montgomery-Dee, M. E. 1993. Reproduction of plant parasitic nematodes on winter rapeseed (Brassica napus spp. oleifera). J. Nematol. (Suppl.) 25:863-868.

2. Bewick, L. S., Young, F. L., Alldredge, J. R., and Young, D. L. 2008. Agronomics and economics of no-till facultative wheat in the Pacific Northwest, USA. Crop Prot. 27:932-942.

3. Boag, B., and Brown, D. K. F. 1985. Soil sampling for virus-vector nematodes. Asp. Appl. Biol. 10:183-189.

4. Brmež, M., Ivezić, M., and Raspudić, E. 2006. Effect of mechanical disturbances on nematode communities in arable land. Helminthologia 43:117-121.

5. Castillo, P., and Vovlas, N. 2007. Pratylenchus, Nematoda, Pratylenchidae: diagnosis, biology, pathogenicity and management. Nematol. Monogr. Perspect. 6:1-530.

6. Ehrler, W. L., Idso, S. B., Jackson, R. D., and Reginato, R. J. 1978. Wheat canopy temperature: relation to plant water potential. Agron. J. 70:251-256.

7. Fenwick, G. R., Heany, R. K., and Mullin, W. J. 1994. Glucosinolates and their breakdown products in food and food plants. CRC Crit. Rev. Food Sci. Nutr. 18:123-201.

8. Ferris, H., Carlson, H. L., and Westerdahl, B. B. 1994. Nematode population changes under crop rotation sequences: consequences for potato production. Agron. J. 86:340-348.

9. Gair, R., Mathias, P. L., and Harvey, P. N. 1969. Studies of cereal nematode populations and cereal yields under continuous or intensive culture (Heterodera avenae, Pratylenchus neglectus, Trichodorus primitivus). Ann. Appl. Biol. 63:503-512.

10. Glazer, I., and Orion, D. 1983. Studies on anhydrobiosis of Pratylenchus thornei. J. Nematol. 15:333-338.

11. Handoo, Z. A., and Golden, A. M. 1989. A key and diagnostic compendium to the species of the genus Pratylenchus Filipjev, 1936 (lesion nematodes). J. Nematol. 21:202-218.
12. Hollaway, G. J., Ophel-Keller, K. M., Taylor, S. P., Burns, R. A., and McKay, A. C. 2003. Effect of soil water content, sampling method and sample storage on the quantification of root lesion nematodes (Pratylenchus spp.) by different methods. Australas. Plant Pathol. 32:73-79.

13. Hollaway, G. J., Taylor, S. P., Eastwood, R. F., and Hunt, C. H. 2000. Effect of field crops on density of Pratylenchus in southeastern Australia: part 2: P. thornei. J. Nematol. 32:600-608.

14. Ingham, R. E. 1994. Nematodes. Pages 459-490. in: Methods of Soil Analysis, Part 2. Microbiological and Biochemical Properties. R. W. Weaver, ed. American Society of Agronomy, Madison, WI.

15. Juergens, L. A., Young, D. L., Schillinger, W. R., and Hinman, H. R. 2004. Economics of alternative no-till spring crop rotations in Washington's wheat-fallow region. Agron. J. 96:154-158.

16. Machado, S., Petrie, S., Rhinhart, R., and Qu, A. 2007. Long-term continuous cropping in the Pacific Northwest: tillage and fertilizer effects on winter wheat, spring wheat, and spring barley production. Soil Tillage Res. 94:473-481.

17. Marley, J. M., and Littler, J. W. 1989. Winter cereal production on the Darling Downs-an 11 year study of fallowing practices. Aust. J. Exp. Agric. 29:807-827.

18. Min, Y. Y., Toyota, K., and Sato, E. 2012. A novel nematode diagnostic method using the direct quantification of major plant-parasitic nematodes in soil by real-time PCR. Nematology 14:265-276.

19. Nombela, G., Navas, A., and Bello, A. 1998. Effects of crop rotations of cereals with vetch and fallow on soil nematofauna in central Spain. Nematologica 44:63-80.

20. Ophel-Keller, K., Hartley, D., McKay, A., Herdina, and Curran, J. 2008. Development of a routine DNA-based testing service for soilborne diseases in Australia. Australas. Plant Pathol. 37:243-253.

21. Orion, D., Amir, J., and Krikun, J. 1984. Field observations on Pratylenchus thornei and its effects on wheat under arid conditions. Rev. Nématol. 7:341345.

22. Ornat, C., Verdejo-Lucas, S., Sorribas, F. J., and Tzortzakakis, E. A. 1999. Effect of fallow and root destruction on survival of root-knot and root-lesion nematodes in intensive vegetable cropping systems. Nematropica 29:5-16.

23. Owen, K. J., Thompson, J. P., and Clewett, T. G. 2010. Pre-cropping with canola decreased Pratylenchus thornei population, arbuscular mycorrhizal fungi, and yield of wheat. Crop Pasture Sci. 61:399-410.

24. Paulitz, T. C., Schroeder, K. L., and Schillinger, W. F. 2010. Soilborne pathogens of cereals in an irrigated cropping system: effects of tillage, residue management, and crop rotation. Plant Dis. 94:61-68.

25. Potter, M. J., Davies, K., and Rathjen, A. J. 1998. Suppressive impact of glucosinolates in Brassica vegetative tissues on root lesion nematode Pratylenchus neglectus. J. Chem. Ecol. 24:67-80.

26. Potter, M. J., Vanstone, V. A., Davies, K. A., Kirkegaard, J. A., and Rathjen, A. J. 1999. Reduced susceptibility of Brassica napus to Pratylenchus neglectus in plants with elevated root levels of 2-phenylethyl glucosinolate. J. Nematol. 31:291-298.

27. Proctor, J. R., and Marks, C. F. 1974. The determination of normalising transformations for nematode count data from soil samples and of efficien sampling schemes. Nematologica 20:395-406.

28. Riga, E., Porter, L. D., Mojtahedi, H., and Erickson, D. 2008. Pratylenchus neglectus, P. thornei, and Paratylenchus hamatus nematodes causing yield reduction to dryland peas and lentils in Idaho. Plant Dis. 92:979.

29. Riley, I. T., and Kelly, S. J. 2002. Endoparasitic nematodes in cropping soils of Western Australia. Aust. J. Exp. Agric. 42:49-56.

30. Schillinger, W. F., Kennedy, A. C., and Young, D. L. 2007. Eight years of annual no-till cropping in Washington's winter wheat-summer fallow region. Agric. Ecosyst. Environ. 120:345-358.

31. Schillinger, W. F., Papendick, R. I., Guy. S. O., Rasmussen, P. E., and Van Kessel, C. 2006. Dryland cropping in the western United States. Pages 365393 in: Dryland Agriculture, 2nd ed. G. A. Peterson, P. W. Unger, and W. A. Payne, eds. Agron. Monogr. 23. American Society of Agronomy, Madison, WI.

32. Schillinger, W. F., and Young, D. L. 2004. Cropping systems research in the World's driest rainfed wheat region. Agron. J. 96:1182-1187.

33. Sheedy, J. G., Raupp, W. J., Thompson, A. L., and Smiley, R. W. 2008 Resistance to root lesion nematodes (Pratylenchus neglectus and P. thornei) of Chinese Spring x Aegilops speltoides addition lines. Plant Dis. Manage. Rep. 2:N038.

34. Sheedy, J. G., Smiley, R. W., Easley, S. A., and Thompson, A. L. 2007. Resistance reaction of Pacific Northwest spring wheat and barley cultivars to root-lesion nematode (Pratylenchus neglectus). Plant Dis. Manage. Rep. 1:CF022

35. Sheedy, J. G., Smiley, R. W., Easley, S. A., and Thompson, A. L. 2008 Resistance of Pacific Northwest spring wheat and barley cultivars to root-lesion nematode (Pratylenchus thornei). Plant Dis. Manage. Rep. 2:N007.

36. Sheedy, J. G., Smiley, R. W., Easley, S. A., and Thompson, A. L. 2008 Root-lesion nematode (Pratylenchus thornei) resistance ratings of Pacific Northwest winter wheat and barley cultivars. Plant Dis. Manage. Rep. 2:N015.

37. Sheedy, J. G., Smiley, R. W., Easley, S. A., and Thompson, A. L. 2008. Resistance of Pacific Northwest winter wheat and barley cultivars to rootlesion nematode (Pratylenchus neglectus). Plant Dis. Manage. Rep. 2:N016. 
38. Sheedy, J. G., Smiley, R. W., Hayes, P. M., Thompson, A. L., Easley, E. A., and Corey, A. E. 2007. Resistance to root-lesion nematode (Pratylenchus thornei) of barley entries in the Coordinated Agriculture Project. Plant Dis. Manage. Rep. 2:N037.

39. Siddique, M. R. B., Hamid, A., and Islam, M. S. 2000. Drought stress effects on water relations of wheat. Bot. Bull. Acad. Sin. 41:35-39.

40. Smiley, R. W. 2009. Root-lesion nematodes reduce yield of intolerant wheat and barley. Agron. J. 101:1322-1335.

41. Smiley, R. W., and Machado, S. 2009. Pratylenchus neglectus reduces yield of winter wheat in dryland cropping systems. Plant Dis. 93:263-271.

42. Smiley, R. W., Merrifield, K., Patterson, L.-M., Whittaker, R. G., Gourlie, J. A., and Easley, S. A.. 2004. Nematodes in dryland field crops in the semiarid Pacific Northwest USA. J. Nematol. 36:54-68.

43. Smiley, R. W., and Nicol, J. M. 2008. Nematodes which challenge global wheat production. Pages 171-187 in: Wheat: Science and Trade. B. F. Carver, ed. Blackwell Publishing, Ames, IA.

44. Smiley, R. W., Sheedy, J. G., and Easley, S. A. 2008. Vertical distribution of Pratylenchus spp. in silt loam soil and Pacific Northwest dryland crops. Plant Dis. 92:1662-1668.

45. Smiley, R. W., Whittaker, R. G., Gourlie, J. A., and Easley, S. A. 2005. Pratylenchus thornei associated with reduced wheat yield in Oregon. J. Nematol. 37:45-54.

46. Smiley, R. W., Whittaker, R. G., Gourlie, J. A., and Easley, S. A. 2005. Suppression of wheat growth and yield by Pratylenchus neglectus in the Pacific Northwest. Plant Dis. 89:958-968.

47. Strausbaugh, C. A., Bradley, C. A., Koehn, A. C., and Forster, R. L. 2004. Survey of root diseases of wheat and barley in southeastern Idaho. Can. J. Plant Pathol. 26:167-176.

48. Stubbs, T. L., Kennedy, A. C., and Schillinger, W. F. 2004. Soil ecosystem changes during the transition to no-till cropping. Pages 105-135 in: New Dimensions in Agroecology. D. Clements and A. Shrestha, eds. Hawthorne Press, New York.

49. Taylor, S. P., and Evans, M. L. 1998. Vertical and horizontal distribution of and soil sampling for root lesion nematodes (Pratylenchus neglectus and $P$. thornei) in South Australia. Australas. Plant Pathol. 27:90-96.

50. Taylor, S. P., Hollaway, G. J., and Hunt, C. H. 2000. Effect of field crops on population densities of Pratylenchus neglectus and P. thornei in southeast- ern Australia: part 1: P. neglectus. J. Nematol. 32:591-599.

51. Thompson, J. P. 1992. Soil biotic and biochemical factors in a long-term tillage and stubble management experiment on a vertisol. 2. Nitrogen deficiency with zero tillage and stubble retention. Soil Tillage Res. 22:339-361.

52. Thompson, J. P., Brennan, P. S., Clewett, T. G., Sheedy, J. G., and Seymour, N. P. 1999. Progress in breeding wheat for tolerance and resistance to rootlesion nematode (Pratylenchus thornei). Australas. Plant Pathol. 28:45-52.

53. Thompson, J. P., Mackenzie, J., and Amos, R. 1995. Root-lesion nematode (Pratylenchus thornei) limits response of wheat but not barley to stored soil moisture in the Hermitage long-term tillage experiment. Aust. J. Exp. Agric. 35:1049-1055.

54. Thompson, J. P., Mackenzie, J., and Sheedy, G. H. 2012. Root-lesion nematode (Pratylenchus thornei) reduces nutrient response, biomass and yield of wheat in sorghum-fallow-wheat cropping systems in a subtropical environment. Field Crops Res. 137:126-140.

55. Thompson, J. P., Owen, K. J., Stirling, G. R., and Bell, M. J. 2008. Rootlesion nematodes (Pratylenchus thornei and P. neglectus): a review of recent progress in managing a significant pest of grain crops in northern Australia. Australas. Plant Pathol. 37:235-242.

56. Townshend, J. L. 1984. Anhydrobiosis in Pratylenchus penetrans. J. Nematol. 16:282-289.

57. Vanstone, V. A., Hollaway, G. J., and Stirling, G. R. 2008. Managing nematode pests in the southern and western regions of the Australian cereal industry: Continuing progress in a challenging environment. Australas. Plant Pathol. 37:220-234.

58. Webb, R. 1990. Effects of nematode Pratylenchus fallax on roots of oilseed rape (Brassica napus var. oleifera). Rev. Nématol. 13:115-117.

59. Whitehead, A. G., and Hemming, J. R. 1965. A comparison of some quantitative methods of extracting small vermiform nematodes from soil. Ann. Appl. Biol. 55:25-38

60. Yan, G. P., Smiley, R. W., and Okubara, P. A. 2012. Detection and quantification of Pratylenchus thornei in DNA extracted from soil using real-time PCR. Phytopathology 102:14-22.

61. Yan, G. P., Smiley, R. W., Okubara, P. A., Skantar, A., Easley, S. A., Sheedy, J. G., and Thompson, A. L. 2008. Detection and discrimination of Pratylenchus neglectus and $P$. thornei in DNA extracts from soil. Plant Dis 92:1480-1487. 